\title{
Baleen whales are not important as prey for killer whales Orcinus orca in high-latitude regions
}

\author{
Amee V. Mehta ${ }^{1, *}$, Judith M. Allen ${ }^{2}$, Rochelle Constantine ${ }^{3}$, Claire Garrigue ${ }^{4}$, \\ Beatrice Jann ${ }^{5}$, Curt Jenner ${ }^{6}$, Marilyn K. Marx ${ }^{7}$, Craig O. Matkin ${ }^{8}$, David K. Mattila9 , \\ Gianna Minton ${ }^{10}$, Sally A. Mizroch ${ }^{11}$, Carlos Olavarría ${ }^{12,17}$, Jooke Robbins ${ }^{13}$, \\ Kirsty G. Russell ${ }^{3}$, Rosemary E. Seton ${ }^{2}$, Gretchen H. Steiger ${ }^{14}$, Gísli A. Víkingsson ${ }^{15}$, \\ Paul R. Wade ${ }^{11}$, Briana H. Witteveen ${ }^{16}$, Phillip J. Clapham ${ }^{11,17}$ \\ ${ }^{1}$ Boston University Marine Program, 7 MBL Street, Woods Hole, Massachusetts 02543, USA \\ ${ }^{2}$ Allied Whale, College of the Atlantic, 105 Eden Street, Bar Harbor, Maine 04609, USA \\ ${ }^{3}$ School of Biological Sciences, Private Bag 92019, University of Auckland, Auckland, New Zealand \\ ${ }^{4}$ Opération Cétacés, BP12827, Noumea 98802, New Caledonia \\ ${ }^{5}$ Swiss Whale Society, Via Nolgio 3, 6900 Massagno, Switzerland \\ ${ }^{6}$ Centre for Whale Research, PO Box 1622, Fremantle, Western Australia 6959, Australia \\ ${ }^{7}$ New England Aquarium, Central Wharf, Boston, Massachusetts 02110, USA \\ ${ }^{8}$ North Gulf Oceanic Society, 3430 Main Street, Suite B1, Homer, Alaska 99603, USA \\ ${ }^{9}$ Hawaiian Islands Humpback Whale National Marine Sanctuary, 726 South Kihei Road, Kihei, Hawaii 96753, USA \\ ${ }^{10}$ Oman Whale and Dolphin Research Group, PO Box 81, Muscat, Oman \\ ${ }^{11}$ National Marine Mammal Lab, Alaska Fisheries Science Center, 7600 Sand Point Way NE, Seattle, Washington 98115, USA \\ ${ }^{12}$ Centro de Estudios del Cuaternario (CEQUA), Plaza Muñoz Gamero 1055, Punta Arenas, Chile \\ ${ }^{13}$ Center for Coastal Studies, PO Box 1036, Provincetown, Massachusetts 02657, USA \\ ${ }^{14}$ Cascadia Research, 218 $1 / 2$ W. 4th Avenue, Olympia, Washington 98501, USA \\ ${ }^{15}$ Marine Research Institute, Skúlagata 4, PO Box 1390, 121 Reykjavík, Iceland \\ ${ }^{16}$ University of Alaska Fairbanks, 118 Trident Way, Kodiak, Alaska 99615, USA \\ ${ }^{17}$ South Pacific Whale Research Consortium, Box 3069, Avarua, Rarotonga, Cook Islands
}

\begin{abstract}
Certain populations of killer whales Orcinus orca feed primarily or exclusively on marine mammals. However, whether or not baleen whales represent an important prey source for killer whales is debatable. A hypothesis by Springer et al. (2003) suggested that overexploitation of large whales by industrial whaling forced killer whales to prey-switch from baleen whales to pinnipeds and sea otters, resulting in population declines for these smaller marine mammals in the North Pacific and southern Bering Sea. This prey-switching hypothesis is in part contingent upon the idea that killer whales commonly attack mysticetes while they are in these high-latitude areas. In this study, we used photographic and sighting data from long-term studies of baleen whales in 24 regions worldwide to determine the proportion of whales that bear scars (rake marks) from killer whale attacks, and to examine the timing of scar acquisition. The results of this study show that there is considerable geographic variation in the proportion of whales with rake marks, ranging from $0 \%$ to $>40 \%$ in different regions. In every region, the great majority of the scars seen were present on the whales' bodies when the animals were first sighted. Less than $7 \%$ (9 of 132) of scarred humpback whales with multi-year sighting histories acquired new scars after the first sighting. This suggests that most killer whale attacks on baleen whales target young animals, probably calves on their first migration from low-latitude breeding and calving areas to high-latitude feeding grounds. Overall, our results imply that adult baleen whales are not an important prey source for killer whales in high latitudes, and therefore that one of the primary assumptions underlying the Springer et al. (2003) prey-switching hypothesis (and its purported link to industrial whaling) is invalid.
\end{abstract}

KEY WORDS: Predation $\cdot$ Killer whale $\cdot$ Baleen whale $\cdot$ Scars $\cdot$ North Pacific $\cdot$ Whaling 


\section{INTRODUCTION}

A pack-hunting animal with a cosmopolitan distribution, the killer whale Orcinus orca is one of the world's top marine predators. The largest of the delphinids, it is known to prey on a remarkably diverse array of animals, from cephalopods and small fishes to sea turtles, marine mammals, and even medium-sized predatory sharks (Caldwell \& Caldwell 1969, Perrin 1982, Hoyt 1984, Jefferson et al. 1991, Pyle et al. 1999). However, at least some killer whale populations appear to have specialized diets (Bigg et al. 1987, Baird et al. 1992, Ford et al. 1998). In the North Pacific, so-called 'Resident-type' killer whales primarily or exclusively eat fish, while 'Transient-type' killer whales primarily consume marine mammals. The diet of a third ecotype, known as 'Offshore,' is not clear, but appears to be focused on fish (Herman et al. 2005). A somewhat similar distinction of foraging specializations has been suggested in Antarctic waters (Pitman \& Ensor 2003), but to date the evidence for distinct ecotypes in this region is equivocal.

Extensive field research and analyses of stomach contents have strongly supported the belief that some killer whales feed primarily or exclusively on marine mammals (Bigg et al. 1987, Heise et al. 2003). However, whether or not large whales constitute an important part of the killer whale's diet has been the subject of much debate. Citing evidence of scars from killer whale attacks on minke whales Balaenoptera acutorostrata that survived attacks, Jonsgård (1968) expressed doubt that killer whales could successfully prey upon healthy larger whales.

Many baleen whales migrate between high-latitude summer feeding grounds and low-latitude winter breeding and calving areas. Corkeron \& Connor (1999) argued that killer whale predation on baleen whale calves is so significant that it was the primary selective force for the evolution of mysticete migration away from high latitudes to low-latitude wintering areas where killer whales are more scarce. Clapham (2001)

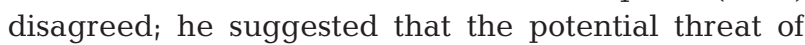
killer whale predation was minimal in the highlatitude feeding areas of the North Atlantic population of the humpback whale Megaptera novaeangliae, and noted that photo-identification data suggested that the majority of animals with scars from killer whale attacks acquire them as calves on their first migration, prior to arrival in high latitudes.

Jefferson et al. (1991) conducted a review of interactions between killer whales and other marine mammals, and included 111 reports of killer whale aggression towards large whales over a 160 yr period. Examination of those incidents classified as 'predatory' (see their Table 1) reveals that, with some exceptions, few large whales were actually killed during these 'attacks'. For example, of 21 'predatory' interactions with humpback whales, only 2 kills were observed, and even these cannot be unequivocally credited to the killer whales. Many of the other incidents listed by Jefferson et al. (1991) for this and other mysticete species involved non-aggressive associations, 'chasing,' or apparently trivial harassment with no lethal outcome. In contrast, lethal attacks by killer whales on common and Antarctic minke whales (Balaenoptera acutorostrata and $B$. bonaerensis, respectively) appear to be more frequent, although the evidence suggests that at least the former species is not an important component of their diet (Jefferson et al. 1991, Ford et al. 2005). Nine of 17 observed predatory interactions with minkes resulted in a kill (e.g. Hall 1986, cited in Jefferson et al. 1991). In Antarctic waters, minke whale remains were identified as the primary item found in the stomachs of killer whales taken by whalers in the 1960s and early 1970s (Shevchenko 1975, Yukhov et al. 1975).

Springer et al. (2003) suggested that over-exploitation of large whales by industrial whaling may have forced killer whales to switch from preying upon baleen whales to eating smaller marine mammals (see also Williams et al. 2004). The authors described supposedly sequential declines in harbor seal Phoca vitulina, northern fur seal Callorhinus ursinus, Steller sea lion Eumetopias jubatus, and sea otter Enhydra lutris populations in the high-latitude North Pacific and southern Bering Sea, beginning in the 1960s. These high-latitude areas include the feeding grounds for several mysticete species including (among others) humpback whales, fin whales Balaenoptera physalus, sei whales $B$. borealis, and blue whales $B$. musculus. The validity of the hypothesis presented by Springer et al. (2003) is premised partly upon the idea that killer whales attack mysticetes (while they are in these highlatitude areas) regularly enough that the loss of those whales to whaling precipitated a major prey-switching event.

Evidence that large whales are commonly killed by killer whales in high latitudes is scant. In the Southern Hemisphere, Shevchenko (1975) examined stomach contents of killer whales, as well as fresh wounds and healed scars caused by these predators on minke whales, sperm whales Physeter macrocephalus, fin whales, and sei whales. He concluded that most attacks on large whales occur in warm waters and not in the productive cold waters of high latitudes.

Dolphin (1987) reached the same conclusion from observations of humpback and killer whales in Alaskan waters, although in his observations of the latter he did not distinguish between fish- and mammaleating types. More recently, Naessig \& Lanyon (2004) 
analyzed photographs of 1436 individually identified humpback whales off eastern Australia and found that only $1 \%$ of scarred whales acquired those scars after their first sighting, further supporting Clapham's (2001) idea that killer whale attacks target young whales. Similarly, documented attacks on gray whales Eschrichtius robustus off California primarily involve newborn calves as they migrate northward with their mothers from calving lagoons in Mexican waters (Jefferson et al. 1991, Goley \& Straley 1994). The most recent review of the evidence for predation by killer whales on large whales was conducted by Reeves et al. (2006). They noted that calves appeared to be attacked with disproportionate frequency relative to other classes, and suggested that baleen whales were taken only opportunistically, perhaps at times (such as migration) when they were particularly vulnerable.

If the majority of killer whale attacks on baleen whales worldwide are indeed focused primarily on migrating calves in lower latitudes, this would undermine a major assumption of the Springer et al. (2003) killer whale prey-switching hypothesis, since it is based upon the idea that large whales represent (or once represented) frequently-taken prey in the highlatitude waters of the North Pacific. That is, killer whales would have to take baleen whales regularly enough as a primary food source to have forced a preyswitch if that food source were removed.

In this study, we used photographic and sighting data from a wide range of baleen whale populations to further investigate this question. In light of the evidence available from field observations and stomach contents, we hypothesized that, with the possible exception of minke whales (Ford et al. 2005), baleen whales larger than calves are not common prey for killer whales in the high-latitude areas that are the focus of the hypothesis put forward by Springer et al. (2003). We examined killer whale scars on baleen whales representing 2 of the 4 mysticete families in 24 regions worldwide to determine the proportion of whales bearing evidence of killer whale attacks, and to determine which age classes were attacked, and where these attacks occurred. If large mysticetes are important prey for killer whales, then over time, surviving individuals should acquire new scars from such attacks. If, however, the overwhelming majority of scars are present at the time of first sighting in highlatitude areas, this would imply that the baleen whales observed were attacked as calves on their first migration to the feeding grounds. The main objectives of this study were: (1) to determine the proportions of whales in several mysticete populations that bear scars from killer whale attacks, (2) to examine whether scars on individually identified whales were present at the first sighting, or whether they were acquired later.

\section{METHODS}

Species and regions sampled. Since the 1970s, there have been numerous long-term studies of baleen whales based upon the identification of individual animals from natural markings (see Hammond et al. 1990). Data from several of these long-term studies were sampled for this research, with humpback whales, blue whales, and pygmy blue whales Balaenoptera musculus brevicauda represented.

For all of the populations concerned, we either visually examined photographs of identified individuals to detect the presence of killer whale-related scarring (rake marks), or performed a computerized query for raked whales within a database that included codes for such scarring (Table 1). Multi-year sighting histories of scarred individuals allowed us to collect information on when these scars were acquired. Specifically, we looked at whether the scars were present by the time of each whale's initial sighting, or were acquired in a subsequent year.

The southwestern Alaska sample was comprised of 10 smaller datasets ranging from Kodiak Island west through the Aleutian Islands, and included humpback whale sightings from the southern part of the Bering Sea. Because of the geographic proximity of the areas, the results (Table 2) represent the combined sample. The 10 smaller datasets had not been thoroughly crossmatched, so some duplication may be present.

For all regions sampled except Mexico, an examination of the severity of scarring and the side of the tail scarred was conducted on all individuals with rake marks. Because of logistical limitations relating to data exchange, we were unable to conduct these analyses on the entire dataset of scarred humpback whales photographed from Mexico (151 individuals), and instead examined a randomly chosen subset of 53 scarred whales from this region.

Assumptions. This work was predicated upon 3 assumptions. The first assumption was that the rakelike scars observed on most of the large whales investigated here resulted from attacks by killer whales and were not created by some other source (e.g. false killer whales, Pseudorca crassidens). This assumption is supported by work conducted in the Antarctic by Schevchenko (1975), and more recently by another study (Mehta 2004). In the latter study, attacks by 6 other predators, including 3 shark species and 3 odontocete species, were shown to be unlikely causes of rake marks observed on humpback whales. Based upon a literature review of the predators' feeding behaviors, examination of their dentition, and estimates of rake mark measurements on humpback whales, the killer whale was shown to be the predator most likely responsible for the scars on hump- 
Table 1. Megaptera novaeangliae, Balaenoptera musculus and Balaenoptera musculus brevicauda. Data sources by species and methods of data collection; P: visual examination of photographs, D: computerized database query

\begin{tabular}{|c|c|c|}
\hline $\begin{array}{l}\text { Species } \\
\text { and region }\end{array}$ & Data & $\begin{array}{l}\text { collection } \\
\text { lethod }\end{array}$ \\
\hline \multicolumn{3}{|l|}{ Humpback whale } \\
\hline Gulf of Maine & Gulf of Maine Humpback Whale Catalog, Center for Coastal Studies (CCS) & $\mathrm{P}$ \\
\hline Scotian Shelf & Northeast Fisheries Science Center (NEFSC) & $\mathrm{P}$ \\
\hline Greenland & North Atlantic Humpback Whale Catalog (NAHWC), College of the Atlantic (COA) & $\mathrm{P}$ \\
\hline Iceland & Years of the North Atlantic Humpback, COA & $\mathrm{P}$ \\
\hline Norway & NAHWC, COA & $\mathrm{P}$ \\
\hline Cape Verde Islands & NAHWC, COA & $\mathrm{P}$ \\
\hline Southwestern Alaska ${ }^{a}$ & $\begin{array}{l}\text { North Pacific Humpback Whale Working Group (NPHWWG), National Marine } \\
\text { Mammal Laboratory (NMML); University of Alaska Fairbanks; } \\
\text { North Gulf Oceanic Society }\end{array}$ & $\mathrm{P}$ \\
\hline Mexico $^{b}$ & $\begin{array}{l}\text { Universidad Nacional Autonoma de Mexico (UNAM); Universidad Autonoma } \\
\text { de Baja California Sur (UABCS); Center for Whale Research; NPHWWG, NMML }\end{array}$ & $\mathrm{P}$ \\
\hline Hawaii & Hawaiian Islands Humpback Whale National Marine Sanctuary (HIHWNMS), CCS & $\mathrm{P}$ \\
\hline American Samoa & Fagatele Bay National Marine Sanctuary; HIHWNMS, CCS & $\mathrm{P}$ \\
\hline New Caledonia & Humpback Whale Catalog of New Caledonia, Opération Cétacés & $\mathrm{P}$ \\
\hline Oman & Oman Whale and Dolphin Research Group & $\mathrm{P}$ \\
\hline Western Australia & Centre for Whale Research & $\mathrm{P}$ \\
\hline Antarctic Peninsula & Instituto Antárctico Chileno & $\mathrm{P}$ \\
\hline New Zealand & University of Auckland, New Zealand Humpback Whale Catalog & $\mathrm{P}$ \\
\hline Vava'u, Tonga & University of Auckland, Tongan Humpback Whale Catalog & $\mathrm{P}$ \\
\hline Gulf of St. Lawrence & NAHWC, COA & $\mathrm{D}$ \\
\hline Newfoundland/Labrador & NAHWC, COA & $\mathrm{D}$ \\
\hline Dominican Republic ${ }^{\mathrm{c}}$ & NAHWC, COA & $\mathrm{D}$ \\
\hline Puerto Rico & NAHWC, COA & $\mathrm{D}$ \\
\hline Virgin Islands & NAHWC, COA & $\mathrm{D}$ \\
\hline \multicolumn{3}{|l|}{ Blue whale } \\
\hline Southeastern Australia & Deakin University Blue Whale Study & $\mathrm{P}$ \\
\hline \multicolumn{3}{|l|}{ Pygmy blue whale } \\
\hline Western Australia & Centre for Whale Research & $\mathrm{P}$ \\
\hline
\end{tabular}

backs. Because this analysis indicated that killer whales did not cause rake marks on North Atlantic right whales, we did not include right whales in the present study.

The second assumption was that killer whale attacks are not always lethal, as is probably the case for any known predator. Injury, or scarring in this case, should be considered evidence of either the prey's ability to escape, or the predator's inefficiency, or both, rather than as a direct indication of predation rate (Schoener 1979). Reeves et al. (2006) asserted that, because many observed killer whale attacks on large cetaceans are not lethal, and as scars from such attacks are fairly common, most attacks are probably unsuccessful.

The final assumption was that all individuals were identifiable and remained so over time. The long-term reliability of natural markings for identifying individual humpback and blue whales has been repeatedly demonstrated (see Hammond et al. 1990). Given the quantity of information on humpback whale flukes, it is very unlikely that even a severe attack by killer whales would result in failure to re-recognize an individual humpback by its markings; this contention is supported by analysis of flukes from Gulf of Maine humpback whales, which are all also identifiable by a second feature, the dorsal fin.

Detection and examination of rake marks. We sampled only photographs of sufficient quality that raketype scars were likely to be detected if present. Rake marks were defined as a set of 3 or more parallel, linear scars approximately equidistant from each other. In cases where particular scars could neither be unequivocally categorized as rake marks, nor be ruled out as such, minimum and maximum frequencies of rakes were recorded and the minimum value was used for subsequent statistical analyses. Each photographic catalog focused on specific body parts, and those were the features most thoroughly examined for rake marks. In the case of humpback whales, ventral tail flukes were inspected, and only those photographs that included the entire ventral fluke area were used. An allowance was made for photographs that provided a 
Table 2. Megaptera novaeangliae, Balaenoptera musculus and Balaenoptera musculus brevicauda. The frequency of rake marks in different sampling regions

\begin{tabular}{|c|c|c|c|c|}
\hline \multirow[t]{2}{*}{$\begin{array}{l}\text { Species } \\
\text { and region }\end{array}$} & \multirow[t]{2}{*}{$\begin{array}{c}\text { Whales } \\
\text { sampled (n) }\end{array}$} & \multicolumn{2}{|c|}{$\begin{array}{l}\text { Whales with } \\
\text { rake marks }\end{array}$} & \multirow[t]{2}{*}{$\begin{array}{c}95 \% \mathrm{CI} \\
(\%)\end{array}$} \\
\hline & & (ind.) & $(\%)$ & \\
\hline \multicolumn{5}{|l|}{ Humpback whale } \\
\hline Gulf of Maine & 700 & $69-77$ & $9.9-11.0$ & $7.9-12.3$ \\
\hline Scotian Shelf & 23 & 4 & 17.4 & $6.4-37.7$ \\
\hline Gulf of St. Lawrence & 154 & 24 & 15.6 & $10.6-22.2$ \\
\hline Newfoundland/Labrador & 1270 & 226 & 17.8 & $15.5-20.0$ \\
\hline Greenland & 163 & 36 & 22.1 & $16.4-29.1$ \\
\hline Iceland & 69 & 9 & 13.0 & $6.8-23.2$ \\
\hline Norway & 49 & 4 & 8.1 & $2.7-19.7$ \\
\hline Southwestern Alaska & 237 & $50-52$ & $21.1-21.9$ & $16.4-26.8$ \\
\hline Antarctic Peninsula & 164 & 2 & 1.2 & $0.1-4.6$ \\
\hline \multicolumn{5}{|l|}{ Western Australia } \\
\hline Flukes: & 1287 & 204 & 15.9 & $14.0-18.0$ \\
\hline Left dorsal: & 1684 & 18 & 1.1 & \\
\hline Right dorsal: & 1656 & 15 & 0.9 & \\
\hline New Zealand & 8 & 3 & 37.5 & $13.5-69.6$ \\
\hline Dominican Republic & 909 & 139 & 15.3 & $13.1-17.8$ \\
\hline Puerto Rico & 358 & 44 & 12.3 & $9.3-16.1$ \\
\hline Virgin Islands & 97 & 13 & 13.4 & $7.9-21.7$ \\
\hline Cape Verde Islands & 13 & 0 & 0.0 & $0.0-20.3$ \\
\hline Mexico & 377 & 151 & 40.1 & $35.2-45.1$ \\
\hline Hawaii & 79 & 14 & 17.7 & $10.7-27.7$ \\
\hline American Samoa & 15 & 3 & 20.0 & $6.3-46.0$ \\
\hline New Caledonia & 166 & 52 & 31.3 & $24.8-38.8$ \\
\hline Vava'u, Tonga & 377 & $68-73$ & $18.0-19.4$ & $14.5-22.3$ \\
\hline Oman & 33 & 3 & 9.1 & $2.4-24.3$ \\
\hline \multicolumn{5}{|l|}{ Blue whale } \\
\hline Southeastern Australia & 27 & 1 & 3.7 & $0.0-19.8$ \\
\hline \multicolumn{5}{|l|}{ Pygmy blue whale } \\
\hline \multicolumn{5}{|l|}{ Western Australia } \\
\hline Flukes: & 19 & 8 & 42.1 & $23.1-63.8$ \\
\hline Left flank: & 79 & 13 & 16.5 & \\
\hline Right flank: & 84 & 7 & 8.3 & \\
\hline
\end{tabular}

complete view with the exception of the axial portion of the leading edge of the flukes (fluke sections 1, 4, 10, and the anterior half of section 2 in Mizroch et al. 1990), as that part is often obscured by the water line, and is also unlikely to be the point of contact for a predator in pursuit. For those individuals that were coded as bearing rake marks from a predator, we examined all available images. Photographs of both the ventral and dorsal sides of the tail flukes were used, as were images of flanks and heads. For blue whales, photo-identification was based upon the mottling pattern on the dorso-lateral flank. Photographs of both right and left flanks, as well as a smaller available set of fluke photographs were used to collect scar data from pygmy blue whales.

Attacks by killer whales on baleen whales in different regions were assessed in 2 ways. The proportion of whales in each sampling region bearing rake marks was calculated; and using multi-year sighting data of identified individual whales (when available), the timing of scar acquisition was determined by comparing photographs from the first sighting of each whale to those from subsequent sightings.

Severity of scarring. The severity of scarring on individuals with rake marks on their tail flukes was evaluated to gain insight into the types of interactions that may have resulted in the observed wounds. The following definitions were used in this evaluation of scarring severity: Mild: $<10 \%$ of the area of the whale's tail flukes covered with rake marks; Moderate: $>10 \%$ and $<50 \%$ of the whale's tail flukes covered with rake marks; Severe: $>50 \%$ of the whale's tail flukes covered with rake marks, or a large ( $>10 \%)$ piece of the fluke missing and seemed to have been lost to a killer whale (i.e. there were rake marks along the edge of the wound).

\section{RESULTS}

\section{Frequency of rake marks}

The proportion of whales in different sampling regions (all latitudes) bearing rake marks ranged from 0 to $>40 \%$ (Table 2). High-latitude sampling in the North Pacific region centered on southwestern Alaska. The sample sizes among the 10 small datasets that comprised that region's total sample ranged from 3 to 46 ind. (mean = 23.7), and the frequency of rake marks ranged from 15.0 to $37.5 \%$. The high latitudes of the Southern Hemisphere were represented by 5 yr of humpback whale photo-identification data from the Antarctic Peninsula. A G-test was used to compare rake mark frequencies within ocean basins (Table 3 ) to determine whether whales in different areas were subject to similar levels of attacks by killer whales; comparisons included all areas of an ocean and, where possible, feeding or breeding grounds only. Rake mark frequency differed significantly in all comparisons, except among North Atlantic breeding grounds.

The Australian and New Zealand coasts provided data for 4 populations. Off southeastern Australia, the only blue whale showing evidence of a killer whale attack had the tip of its left pectoral fin bitten off (P. Gill, M. Morrice pers. comm.), although, due to their 
Table 3. Megaptera novaeangliae. Within-ocean inter-area comparisons for the frequency of rake marks on humpback whale flukes. G-test values are given together with degrees of freedom (df) and level of significance. Oceans represented by only one sample (western Australia [Indian Ocean], Oman [Indian Ocean] and the Antarctic Peninsula [Southern Ocean]) were excluded. The datasets for 'North Atlantic: All' and 'North Pacific: All' may not be entirely independent because they probably include an unknown number of individuals photographed in both feeding and breeding areas. ns: not significant

\begin{tabular}{|c|c|c|c|c|c|}
\hline Ocean & $\begin{array}{l}\text { Number } \\
\text { of areas }\end{array}$ & $\mathrm{N}$ & $G$ & $\mathrm{df}$ & $\mathrm{p}$ \\
\hline \multicolumn{6}{|l|}{ North Atlantic: } \\
\hline All & 11 & 3805 & 38.457 & 10 & $<0.001$ \\
\hline Feeding grounds & 7 & 2428 & 31.617 & 6 & $<0.001$ \\
\hline Breeding grounds & S 4 & 1377 & 6.017 & 3 & ns \\
\hline \multicolumn{6}{|l|}{ North Pacific: } \\
\hline All & 3 & 693 & 32.700 & 2 & $<0.001$ \\
\hline Breeding grounds & s 2 & 456 & 15.456 & 1 & $<0.001$ \\
\hline \multicolumn{6}{|l|}{ South Pacific: } \\
\hline Breeding grounds & s 4 & 566 & 12.330 & 3 & $<0.01$ \\
\hline
\end{tabular}

mostly surface feeding-habit, the flukes of blue whales are rarely photographed. For pygmy blue whales and humpback whales off western Australia, rake mark frequencies were scored on 3 body regions, i.e. the left and right flanks or dorsal fins and ventral tail flukes. The rake mark frequency on ventral tail flukes was considerably higher than that on other body regions. A small set $(n=8)$ of humpback whales photographed off New Zealand showed a high scarring rate (3 whales, $37.5 \%)$.

Some low-latitude areas that were sampled represent breeding grounds for populations that were also sampled in high latitudes. For example, humpback whales from all of the North Atlantic feeding grounds winter in the West Indies (Katona \& Beard 1990). The NAHWC (North Atlantic Humpback Whale Catalog) database was queried to determine rake mark frequencies for humpbacks in the waters of the Dominican Republic (including Silver Bank, Navidad Bank, and Samana Bay), Puerto Rico, and the Virgin Islands. On the low-latitude breeding grounds, the rake mark frequencies ranged from 12.3 to $15.3 \%$ $($ mean $=14.4 \%)$. Direct examination of a small set $(n=$ 13) of humpback whale photographs from the Cape Verde Islands, which have been proposed as a breeding ground for some whales that feed in the eastern North Atlantic (Jann et al. 2003), uncovered no evidence of killer whale attacks. Of the humpbacks sampled from Mexico, several had also been sighted in Alaskan waters, off the Pacific Canadian and U.S. coasts, and/or around Hawaii. The highest proportion of whales with rake marks was seen in the Mexico sample.

\section{Severity of scarring}

We evaluated the severity of predatory interactions across several populations based on rake-like scars on a shared feature, the tail flukes. Among the 69 scarred humpback whales in the Gulf of Maine, 52 (75.4\%) had mild raking, (as defined above), 16 (23.2\%) had moderate scarring, and only one animal (1.4\%) was severely scarred. Two-thirds (24) of the 36 Greenland area humpbacks bearing scars had only mild scarring; one-third (12) had moderate scarring. In the regional sample of humpback whales from southwestern Alaska, $84.0 \%$ (42 of 50) had only mild rake marks and $16 \%$ (8) were moderately scarred. The region with the highest frequency of rake marks, Mexico, also had the greatest proportion of severely scarred humpbacks, but that frequency was still only $7.5 \%$ (4 of 53). Moderate levels of raking were seen on $26.4 \%$ (14) of the whales and $66.0 \%$ (35) had only mild rake marks.

Although it is not relevant to the present analysis, we examined whether there was any lateral bias in the location of rake marks on the tails or bodies of whales; there was no significant bias to right or left side for any of the populations studied.

\section{Acquisition of rake marks}

Multi-year resighting history data were available for 3 of the humpback whale datasets examined (Gulf of Maine, Greenland, and Mexico). Of scarred animals with such resighting histories (totaling 132 humpback whales), $86.3 \%$ to $100 \%$ had those scars the first time they were sighted, depending on the region (Fig. 1).

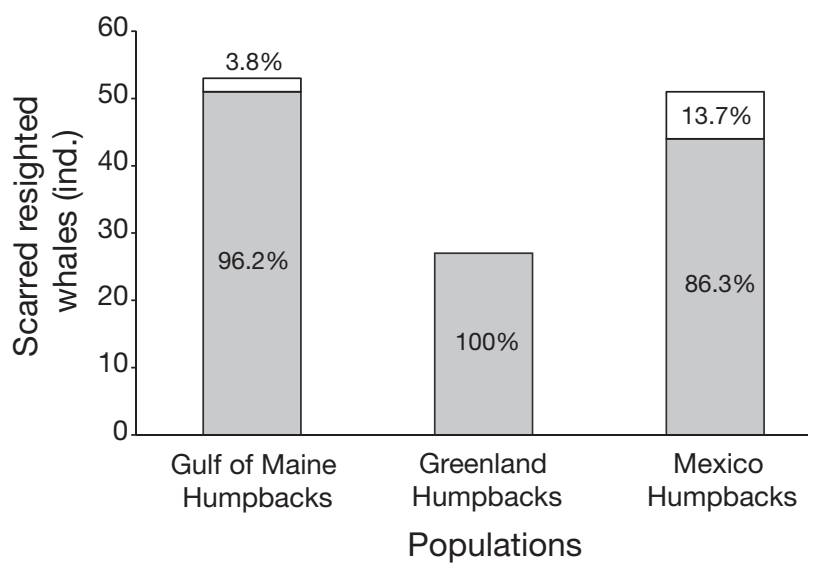

Fig. 1. Megaptera novaeangliae. Acquisition of rake marks in humpback whales with multi-year sighting histories. Although some re-sighted scarred whales acquired new rake marks over time, the majority of whales with scars bore those scars at their first sighting. Gray bars: scars seen at first sightings of animals; white bars: scars not seen at first sightings of animals, but observed subsequently 
The range of resighting records for humpback whales spanned 1 to $24 \mathrm{yr}$, with a mean of $8.5 \mathrm{yr}$ (SD = 5.14). Among Gulf of Maine humpbacks bearing the scars, only $2(3.8 \%)$ individuals gained rake marks after the first time they were photographed. Of the 5 scarred individuals for which the year of birth was known, 4 were attacked in their first year prior to their arrival on this high-latitude feeding ground. Among raked humpback whales off western Greenland, none of the individuals acquired scars subsequent to their first sighting. Of the examined subset of 53 scarred whales from Mexico, 51 had resighting histories that allowed us to consider timing of scar acquisition. Seven $(13.7 \%)$ of the 51 whales acquired new or additional rake marks after their first sighting.

\section{DISCUSSION}

There was considerable geographical variation in the frequency of rake-type scarring on the bodies of large whales. However, there was also a high degree of consistency in the timing of acquisition of those scars, with the great majority of the marks being observed when whales were first sighted.

\section{Frequency of rake marks}

Katona et al. (1988) sampled fluke photographs of whales in the western North Atlantic for parallel scars, and found them in $14 \%$ of 3365 humpbacks, about $1 \%$ of 150 blue whales, and about $1 \%$ of 140 fin whales. However, their comment that these results corresponded with the relative tendencies of the species to fluke up when diving strongly suggests that few fluke photographs were taken of blue and fin whales. Naessig \& Lanyon (2004) found that $17 \%$ of 1436 humpback whales off eastern Australia had scarring attributable to predatory attacks; this is very similar to the $15.9 \%$ observed in our western Australian sample. G. Steiger et al. (unpubl.) conducted an analysis of the frequency of killer whale rake marks on humpback whales in the North Pacific, using a larger sample size and broader geographic representation than the present study. Overall, they found that $15 \%$ of humpback whale tails showed such scars. They concluded (as we do) that humpbacks were at higher risk of killer whale attack in Mexican waters than elsewhere in the North Pacific, and that most attacks on humpbacks occur primarily in low-latitude breeding areas.

In our study, the majority of whales were sampled for scarring by examination of photographs of their tail flukes. When more than one body part was available for sampling (pygmy blue whales and humpback whales off western Australia) it did not appear that fluke sampling underestimated rake mark frequencies. Fluke photographs alone would have limited use in the case of pygmy blue whales, due to their infrequent fluking behavior.

Individual lines making up rake marks on the flukes of humpback whales in the Gulf of Maine were clearly visible years after the scars were first photographed. Scars on humpback whale dorsal fins, however, seemed to fade much more quickly, and were often undetectable or unrecognizable as rake marks only 2 or 3 yr after they were first photographed.

Although killer whales are more densely concentrated in the colder, productive waters of high latitudes (e.g. Hammond 1984, Wade \& Gerrodette 1993, Rice 1998), they occur in every ocean at all latitudes. Whether any killer whale populations undertake predictable seasonal migrations is not clear. Some, such as some North Pacific mammal-eating killer whales, have been sighted in both Southeast Alaska and in Monterey Bay, California (Goley \& Straley 1994), but this may simply reflect a very large home range rather than migration sensu stricto. The variation in the proportion of whales bearing rake marks from killer whale interactions in different regions (Tables 2 \& 3) may in some areas be attributable to the abundance or scarcity of killer whales. For example, while killer whales occur along most of the western coast of North America and number in the low hundreds there (Baird 2001), they appear to be far less common in most of the North Atlantic, although reliable abundance estimates are unavailable (Katona et al. 1988, Mitchell \& Reeves 1988, Wenzel \& Sears 1988). The ecology of the mammal-eating and the piscivorous killer whales is quite well understood in the North Pacific (Ford et al. 1998, Baird 2001), however, the existence and relative abundances of corresponding foraging specializations in other parts of the world are not clear.

In the high-latitude feeding areas of the humpback whale in the North Atlantic, the rake mark frequencies ranged from 8.1 (around Norway) to 22.1\% (around Greenland) $($ mean $=15.3 \%)$. On the low-latitude breeding grounds, the rake mark frequencies ranged from 12.3 to $15.3 \%$ (mean $=14.4 \%)$. Whales from all of the feeding areas mix on the breeding grounds in the West Indies (Katona \& Beard 1990), and the lack of significance in the North Atlantic breeding area comparison (Table 3) is probably due to the fact that the areas sampled (with the exception of the Cape Verde Islands) are not separate breeding areas, but rather parts of a single common wintering range where whales from different feeding grounds mix. The different rake mark frequencies among feeding areas, and the fact that most of the scarred whales have these marks prior to their first sighting in high latitudes, sug- 
gest that humpbacks migrating from the West Indies to the waters around Greenland are subject to more interactions with killer whales along their migratory route than humpbacks migrating to other areas.

\section{Severity of scarring}

In all regions, approximately two-thirds or more of the animals with rake marks had only mild scarring, and less than $8 \%$ had severe scarring. Naessig \& Lanyon (2004) categorized scarring on humpback whales off eastern Australia as either 'minor' or 'major' depending on whether the animal concerned had, respectively, 1 to 3 sets of rake marks, or 4 or more sets and/or a portion of the tail missing. This rather less conservative classification (than that which we used) likely accounts for the greater proportion of whales with 'major' scarring in their sample (107 of 248 individuals, or $43 \%$ ).

These results can be interpreted in one of 2 ways: (1) attacks resulting in severe damage (as defined here) are rare, or (2) attacks resulting in severe damage are often fatal. Dolphin (1987) described the killer whale as an 'occasional predator' of large whales. He likened the relationship between the cetacean predator and prey to the usually non-aggressive relationship between lions and large ungulates, noting that successful attacks resulting in a kill are made only rarely in both cases. He described 5 classes of interactions between killer whales and baleen whales, ranging from the most common situation, in which each species ignored the other, to the infrequent actual attack, the only class in which physical contact occurred between predator and prey. Our finding of a relatively higher frequency of mild scarring on baleen whales might suggest that the marks were caused by a predator's quick attempt to assess the animal, or through harassment.

Jefferson et al. (1991) noted that the aggressive behavior exhibited by killer whales when they are hunting other marine mammals might also be used in non-feeding situations. Citing evidence that attacks on gray whale calves by killer whale females and young were of significantly longer duration than attacks by adult males, Reeves et al. (2006) suggested that the purpose of at least some attacks may be to provide learning opportunities for young killer whales.

\section{Acquisition of rake marks}

Although there was a wide range in the proportion of whales bearing rake marks in various regions, the great majority of whales with the scars had them at their first sighting. Less than $7 \%$ of all scarred, resighted humpback whales gained new or additional rake marks after their first sighting. From his study of humpback whales in Alaska, Dolphin (1987) noted that small humpbacks acquired new rake marks more frequently than adults. Similarly, only $3 \%$ of the sample of eastern Australian humpback whales examined by Naessig \& Lanyon (2004) acquired rake marks after their initial sighting. They also reported evidence of recent attacks on 2 subadult humpbacks and one documented lethal attack on a calf; all of these events occurred along the migratory route ${ }^{1}$.

Overall, the results reported here and elsewhere strongly suggest that killer whales attack mysticetes when the latter are young. For humpbacks photographed for the first time in high-latitude areas like the Gulf of Maine and Greenland, these results suggest that the whales are attacked before they reach these areas, possibly on migration from their low-latitude breeding and calving grounds. On the Gulf of Maine feeding ground, Clapham \& Mayo (1990) reported that no mother lost a calf between sightings within a single summer for over $10 \mathrm{yr}$. This would indicate that calf mortality resulting from killer whales or any other causes occurs during migration and not on the highlatitude feeding grounds. This observation is consistent with the scarring data.

\section{Synthesis}

The results of this study indicate considerable geographic variation in the frequency of rake marks on baleen whales, a finding that suggests variation in the risk of attack faced by different populations. Scar frequency may be correlated with the abundance of mammal-eating killer whales, although not necessarily in the areas in which the mysticetes concerned were photographed. Analysis of the timing of scar acquisition indicates that most large whales bearing rakes have these marks at first sighting; this provides strong support for the idea that most attacks occur on young whales, probably while on migration from lower latitudes.

The scar data suggest that adult baleen whales face little risk of predation by killer whales. This is consistent with the rarity of documented attacks on adults, as well as with other evidence. Clapham (1993) noted that the lack of stable groups among mysticetes might

\footnotetext{
1 However, we note that the photographic evidence for the 2 'fresh predatory attacks' (Naessig \& Lanyon 2004, their Fig. 3a,b) appears to be ambiguous; most of the rake mark scars shown do not seem to be recent, and it is not clear whether the raw areas in their Fig. 3a come from a predatory attack or aggressive intrasexual interactions
} 
reflect the lack of need for predator detection and defense, as group size in many taxa is determined by this factor.

Calves of all large whale species may be small enough for killer whales to invest the energy to attack them with minimal danger to themselves (Reeves et al. 2006). Calf mortality is greatest on the migration route for eastern gray whales (Jefferson et al. 1991, Goley \& Straley 1994), while attacks in high-latitude areas on mysticetes other than minke whales are rare (despite the highly visible nature of such attacks). In the Southern Hemisphere, fresh wounds from killer whales on large whales occur only in temperate-warm waters (Shevchenko 1975).

We do not dispute that killer whales take large whales, at least occasionally. The more pertinent issue is how frequently, and where? For the hypothesis of Springer et al. (2003) to be tenable, large whales would have had to be taken as a primary food source, and frequently enough so that the loss of this source to whaling would have forced a prey-switching event.

The data reported here suggest that attacks by killer whales on large whale species primarily involve calves (and perhaps young juveniles) prior to their arrival in high latitudes. The scar data and general paucity of records of attacks make it unlikely that populations of killer whales in high latitudes once relied upon big whales as a primary food source. We cannot rule out the possibility that killer whales involved in any purported prey-switching event were previously making their primary living from calves or other migrating whales in low latitudes, and that the prey switch was precipitated by the loss of this source through depletion of these large whales at the other end of the migration route (i.e. in high latitudes during summer). However, for this to have been the case, it would have been necessary for the killer whales concerned to have not only switched prey, but also to have relocated from tropical/subtropical waters to the to high-latitude areas that are the focus of declines central to the hypothesis of Springer et al. (2003). Such a major change in range is not consistent with what is known of mammal-eating killer whales (Black et al. 1997, M. Dahlheim pers. comm.).

As noted by many other authors (DeMaster et al. 2006, Mizroch \& Rice 2006, Wade et al. 2007), there are additional reasons to regard the hypothesis of Springer et al. (2003) as weak. Closer examination of the data used by Springer et al. (2003) and of other information from the eastern North Pacific indicates that: (1) the reported declines of prey species were not sequential as stated; (2) because of increasing numbers of gray and humpback whales, large whale biomass remained high through much of the period concerned; (3) minke whales and small cetaceans (known or thought to be regular prey for killer whales) were abundant throughout the period; and (4) populations of pinnipeds and sea otters remained stable or increased in other areas, despite intensive whaling and high abundances of mammal-eating killer whales. In short, if killer whales were dependent upon large whales, there would have been no compelling reason for a prey switch to pinnipeds and sea otters during the period in question. More to the point, the paucity of documented attacks on large whales, notably in areas with many years of high observer effort (e.g. southeastern Alaska) adds to the present conclusion that large whales, while occasionally taken by killer whales, have never been a primary high-latitude food source for this most notorious of top predators. Reeves et al. (2006) suggest that, if large whales are only an opportunistic food source for killer whales, declines in the smaller marine mammals that constitute their primary prey may have actually caused an increase in attacks on whales (in other words, the reverse of the Springer et al. (2003) hypothesis).

Recently, Whitehead \& Reeves (2005) proposed that some groups of killer whales may have been dependent not upon live whales, but upon carcasses 'provided' by industrial whaling, and that the loss of this food source when whaling ceased could have led to increased attacks on pinnipeds, living large whales, sea otters and small cetaceans. However, as they note, the extent to which killer whale predation has contributed to apparent declines of some populations of pinnipeds and cetaceans was beyond the scope of their study, and 'remains an open and controversial question.' Similarly, the present study provides no insight into the cause of any such declines; rather, it suggests that a key assumption underlying the prey-switching proposed by Springer et al. (2003): that living large whales in high latitudes were an important food source for killer whales prior to industrial whaling, is not valid.

Acknowledgements. This study was supported in part by funding from the Marine Mammal Commission. We are grateful to the many researchers who have contributed data to the North Atlantic Humpback Whale Catalog, the Gulf of Maine Humpback Whale Catalog, the North Pacific Humpback Whale Working Group, the Humpback Whale Catalog of New Caledonia, the New Zealand Humpback Whale Catalog, the Tongan Humpback Whale Catalog, the Deakin University Blue Whale Study, the Centre for Whale Research, Instituto Antartico Chileno Catalog and the Oman Whale and Dolphin Research Group. We thank A. Aguayo-Lobo, K. Balcomb, J. Calambokidis, S. Cerchio, J. Darling, M. Ferrari, D. Ferrari, P. Gill, L. Herman, J. Jacobsen, F. Larsen, L. Medrano, N. Øien, J. Urban, and O. von Ziegesar for their contributions. We thank the staff of the Protected Species Branch of the Northeast Fisheries Science Center for their assistance and G. Rosenthal, M. Dahlheim and J. Durban for helpful comments on previous versions of this manuscript. All photo-identification work in U.S. waters was conducted under the appropriate permits from NOAA Fisheries. 


\section{LITERATURE CITED}

Baird RW (2001) Status of killer whales, Orcinus orca, in Canada. Can Field-Nat 115:676-701

Baird RW, Abrams PA, Dill LM (1992) Possible indirect interactions between transient and resident killer whales: implications for the evolution of foraging specializations in the genus Orcinus. Oecologia 89:125-132

Bigg MA, Ellis GM, Ford JKB, Balcomb KC III (1987) Killer whales: a study of their identification, genealogy, and natural history in British Columbia and Washington State. Phantom Press, Nanaimo

Black NA, Schulman-Janiger A, Ternullo RL, Guerrero-Ruiz M (1997) Killer whales of California and Western Mexico: a catalog of photo-identified individuals. NOAA Tech Memo NMFS-SWFSC-247

Caldwell DK, Caldwell MC (1969) Addition of the leatherback sea turtle to the known prey of the killer whale, Orcinus orca. J Mammal 50:636

Clapham PJ (1993) Social organization of humpback whales on a North Atlantic feeding ground. Symp Zool Soc Lon 66:131-145

Clapham PJ (2001) Why do baleen whales migrate? A response to Corkeron and Connor. Mar Mamm Sci 17: 432-436

Clapham PJ, Mayo CA (1990) Reproduction of humpback whales, Megaptera novaeangliae, observed in the Gulf of Maine. Rep Int Whal Comm Special Issue 12:171-175

Corkeron PJ, Connor RC (1999) Why do baleen whales migrate? Mar Mamm Sci 15:1228-1245

DeMaster DP, Trites AW, Clapham P, Mizroch S, Wade P, Small RJ, Ver Hoef J (2006) The sequential megafaunal collapse hypothesis: testing with existing data. Prog Oceanogr 68:329-342

Dolphin WF (1987) Observations of humpback whale, Megaptera novaeangliae-killer whale, Orcinus orca, interactions in Alaska: comparison with terrestrial predator-prey relationships. Can Field-Nat 101:70-75

Ford J, Ellis G, Barrett-Lennard L, Morton A, Palm R, Balcomb K (1998) Dietary specialization in two sympatric populations of killer whales (Orcinus orca) in coastal British Columbia and adjacent waters. Can J Zool 76: 1456-1471

Ford JKB, Ellis GM, Matkin DR, Balcomb KC, Briggs D, Morton AB (2005) Killer whale attacks on minke whales: prey capture and antipredator tactics. Mar Mamm Sci 21: 603-618

Goley PD, Straley JM (1994) Attack on gray whales (Eschrichtius robustus) in Monterey Bay, California, by killer whales (Orcinus orca) previously identified in Glacier Bay, Alaska. Can J Zool 72:1528-1530

Hammond PS (1984) Abundance of killer whales in Antarctic Areas II, III, IV and V. Rep Int Whal Comm 34:543-548

Hammond PS, Mizroch SA, Donovan GP (1990) Individual recognition of cetaceans: use of photo identification and other techniques to estimate population parameters. International Whaling Commission, Cambridge

Hall JD (1986) Notes on the distribution and feeding behavior of killer whales in Prince William Sound, Alaska. In: Lockard J, Kirkevold B (eds) Behavioral biology of killer whales. Alan R. Liss, New York, p 69-83

Heise K, Barrett-Lennard LG, Saulitis E, Matkin C, Bain D (2003) Examining the evidence for killer whale predation on Steller sea lions in British Columbia. Aquat Mamm 29: 325-334

Herman DP, Burrows DG, Wade PR, Durban JW, Matkin CO, LeDuc RG, Barrett-Lennard RG, Krahn, MM (2005) Feed- ing ecology of eastern North Pacific killer whales (Orcinus orca) from fatty acid, stable isotope, and organochlorine analyses of biopsies. Mar Ecol Prog Ser 302:275-291

Hoyt E (1984) Orca: the whale called killer. Camden House Publishing, North York, Ontario

Jann B, Allen J, Carrillo M, Hanquet $S$ and 6 others (2003) Migration of a humpback whale (Megaptera novaeangliae) between Cape Verde Islands and Iceland. J Cetacean Res Manag 5:125-129

Jefferson TA, Stacey PJ, Baird RW (1991) A review of killer whale interactions with other marine mammals: predation to co-existence. Mamm Rev 21:151-180

Jonsgård A (1968) Another note on the attacking behaviour of killer whale (Orcinus orca). Norsk Hvalfangst-Tidende 6: 175-176

Katona SK, Beard JA (1990) Population size, migrations and feeding aggregations of the humpback whale (Megaptera novaeangliae) in the western North Atlantic Ocean. Rep Int Whal Comm Special Issue 12:295-305

Katona SK, Beard JA, Girton PE, Wenzel F (1988) Killer whales (Orcinus orca) from the Bay of Fundy to the Equator, including the Gulf of Mexico. Rit Fiskideildar 11: 205-224

Mehta AV (2004) How important are baleen whales as prey for killer whales (Orcinus orca) in high latitudes? MA thesis, Boston University

Mitchell E, Reeves RR (1988) Records of killer whales in the western North Atlantic, with emphasis on eastern Canadian waters. Rit Fiskid 11:161-193

Mizroch SA, Rice DW (2006) Have North Pacific killer whales switched prey species in response to depletion of the great whale populations? Mar Ecol Prog Ser 310:235-246

Mizroch SA, Beard JA, Macgill L (1990) Computer assisted photo-identification of humpback whales. Rep Int Whal Comm Special Issue 12:63-85

Naessig PJ, Lanyon JM (2004) Levels and probable origin of predatory scarring on humpback whales (Megaptera novaeangliae) in east Australian waters. Wildl Res 31: 163-170

Perrin WF (ed) (1982) Report of the workshop on identity, structure and vital rates of killer whale populations, Cambridge, England, June 23-25, 1981. Rep Int Whal Comm 32:617-632

Pitman RL, Ensor P (2003) Three different forms of killer whales in Antarctic waters. J Cetacean Res Manag 5: 131-139

Pyle P, Schramm MJ, Keiper C, Anderson SD (1999) Predation on a white shark (Carcharodon carcharias) by a killer whale (Orcinus orca) and a possible case of competitive displacement. Mar Mamm Sci 15:563-568

Reeves RR, Berger J, Clapham PJ (2006) Killer whales as predators of large baleen whales and sperm whales. In: Estes JA, DeMaster DP, Doak DF, Williams TM, Brownell, RL Jr (eds) Whales, whaling and ecosystems. University of Chicago Press, Chicago, p 174-187

Rice DW (1998) Marine mammals of the world: systematics and distribution. Spec Publ 4, Society for Marine Mammalology, Lawrence

Schoener TW (1979) Inferring the properties of predation and other injury-producing agents from injury frequencies. Ecology 60:1110-1115

Shevchenko VI (1975) The nature of the interrelationships between killer whales and other cetaceans. Morskie Mlekopitayshchie Chast 2:173-174 (translated from Russian)

Springer AM, Estes JA, van Vliet GB, Williams TM, Doak DF, Danner EM, Forney KA, Pfister B (2003) Sequential megafaunal collapse in the North Pacific Ocean: an ongo- 
ing legacy of industrial whaling? Proc Natl Acad Sci USA 100:12223-12228

Wade P, Barrett Lennard L, Black N, Brownell RL Jr and 23 others (2007) Marine mammal abundance, biomass, and trends in the eastern North Pacific: a reanalysis of evidence for sequential megafauna collapse. Mar Mamm Sci doi: 10.1111/j.1748-7692.2006.00093.x

Wade PR, Gerrodette T (1993) Estimates of cetacean abundance and distribution in the Eastern Tropical Pacific. Rep Int Whal Comm 43:477-493

Wenzel F, Sears R (1988) A note on killer whales in the Gulf of

Editorial responsibility: Otto Kinne (Editor-in-Chief), Oldendorf/Luhe, Germany
St. Lawrence, including an account of an attack on a minke whale. Rit Fiskid 11:202-204

Whitehead H, Reeves R (2005) Killer whales and whaling: the scavenging hypothesis. Biol Lett 1:415-418

Williams TM, Estes JA, Doak DF, Springer, AM (2004) Killer appetites: assessing the role of predators in ecological communities. Ecology 85:3373-3384

Yukhov VL, Vinogradova EK, Medvedev LI (1975) The food species of killer whales in the Antarctic and adjacent waters. Morskie Mlekopitayshchie Chast 2:183-185 (translated from Russian)

Submitted: December 5, 2005; Accepted: April 20, 2007 Proofs received from author(s): September 30, 2007 